\title{
Organizational Restructuring of Regional Apparatus of Sleman Regency, Yogyakarta, Regarding Spatial Planning
}

\author{
Pradipta Wijonugroho ${ }^{1}$, FX. Sumarja ${ }^{2}$ \\ \{diptawijo@hotmail.com¹,fxsmj.unila@gmail.com² \\ Faculty of Law University of Lampung, Indonesia ${ }^{12}$
}

\begin{abstract}
This study aims to investigate the urgency of organizational restructuring of regional apparatus in regard to spatial planning and the authority of Land and Spatial Planning Agency of Sleman Regency, Yogyakarta. The study employed a doctrinal approach. The results of the study suggest that the urgency of organizational restructuring of regional apparatus in Sleman Regency is for the effectiveness of the implementation of spatial planning. The authority of Land and Spatial Planning Agency of Sleman Regency is not limited to the spatial planning of the Sultanate Land and Regency Land.
\end{abstract}

Keywords: Restructuring; Land Agency; Spatial Planning

\section{Introduction}

In the course of eight years (2009-2016), the Government of Sleman Regency of Yogyakarta restructured the local organizational apparatus for three times. The restructuring was characterized by three regional regulations, namely: 1) Regional Regulation of Sleman Regency No. 9 of 2009 on the Local Organizational Apparatus of Sleman; 2) Regional Regulation of Sleman Regency No. 8 of 2014 on the Second Amendment to the Regional Regulation of Sleman No. 9 of 2009; and 3) Regional Regulation of Sleman Regency No. 11 of 2016 on the Formation and Structure of Regional Apparatus of Sleman. The last regulation lifted the previous two regional regulations . Organizational restructuring aimed to create a more effective and efficient organization.

As stipulated in Article 7 Paragraph 2 of Law No. 12 of 2013 on the Privilege of Yogyakarta Special Region (DIY), one of the privileges is the authority over spatial planning which is further specified in the Special Regional Regulation (Special Regional Regulation). In this regard, Special Regional Regulation refers to Special Regional Regulation DIY No. 2 of 2017 on the Sultanate Land and the Regency Land. Other rights and authority remain subject to applicable laws and regulations. On the other hand, at the national level, spatial planning is the authority of Ministry of Agrarian Affairs and Spatial Planning/National Land Agency. Previously, Ministry of Public Works and Housing was responsible for spatial planning. Following the laws and regulations, the local government of Sleman Regency performed organizational restructuring of regional apparatus. 
Based on the explanation above, this study aims to 1) investigate the urgency of organizational restructuring of regional apparatus related to spatial planning in Sleman Regency in Yogyakarta and 2) examine the authority of Land and Spatial Planning Agency of Sleman Regency in organizational restructuring of spatial planning.

\section{Research Methods}

This research uses an analytical descriptive approach. This study is conducted with the aim of describing and analyzing the urgency of organizational restructuring of regional apparatus regarding to spatial planning in Sleman Regency, Yogyakarta, and the authority of Land and Spatial Planning Agency in Sleman Regency, especially in spatial planning. The primary and secondary data of the study were collected and analyzed based on the law concerning spatial planning.

\section{Discussion}

3.1 The Urgency of Organizational Restructuring of Regional Apparatus Regarding to Spatial Planning in Sleman Regency

In order to build infrastructure, President Jokowi needed a synergy of all sectors; spatial and agrarian sectors were no exception. Thus, the president appointed ministers who were able to manage those sectors. This is in line with the 1945 Constitution of Republic of Indonesia Article 17 stating that the President, in running the government, is assisted by ministers. In 2015, new ministry called Ministry of Agrarian Affairs and Spatial Planning was formed. The legal basis for the formation of this ministry was the President Regulation No. 17 of 2015 on Ministry of Agrarian Affairs and Spatial Planning.

In the previous term, land and spatial planning were handled by different agencies. The land sector was the responsibility of BPN (National Land Agency), while spatial planning was the authority of Ministry of Public Work Directorate General of Spatial Planning. The local government of Sleman restructured regional apparatus for the last time in 2016. In carrying out the organizational restructuring of regional apparatus, the local government of Sleman complied with the laws and regulations stipulated by both central government and local governments (province). In regions, (provinces/regencies/cities) authority over the strategic field was continued and implemented by the local governments.

The elements of local government are governor, Regional Representative Council (DPRD), and regional apparatus. Article 5 of Regional Regulation No. 18 of 2016 on Regional Apparatus stipulates that there are several types of regional apparatus at the provincial and regency/city level; one of which is agency. On that basis, the local government of Sleman specifies Regional Regulation No. 11 of 2016 on the Formation and Structure of Regional Apparatus of Sleman. Since the regulation took effect, BPPD of Sleman Regency was transformed into Land and Spatial Planning Agency of Sleman Regency. The Land and Spatial Planning Agency of Sleman Regency supports the duties of regional heads. The agency is responsible for formulating regional policies, which are quite specific, on land and spatial planning. Viewed from the effectiveness point of view, it is necessary for the local government of Sleman Regency to conduct organizational restructuring of regional apparatus. Many divisions, sub-divisions, and sections were added to the Land and Spatial Planning 
Agency of Sleman Regency. Consequently, regional budget, including professional human resources, was increased in order to run the spatial planning authority.

Furthermore, restructuring was carried out based on the organizational structure of regional apparatus by taking into account these principles: 1) intensity of government affairs and regional potential; 2) efficiency; 3) effectiveness; 4) division of duties; 5) control range; 6) clear working procedures; and 7) flexibility. Therefore, the urgency of restructuring of Land and Spatial Planning of Sleman Regency was to carry out duties on land and particularly spatial planning more effectively.

\subsection{The Authority of Land and Spatial Planning Agency of Sleman Regency over Spatial Planning}

Organizational restructuring of regional apparatus in Sleman Regency based on Regional Regulation No. 11 of 2016 on the Formation and Structure of Regional Apparatus was followed up by the stipulation of Regent Regulation No. 66 of 2016. The legal basis of regional apparatus was previously Regional Regulation of Sleman No. 9 of 2009 on the Second Amendment to the Regional Regulation of Sleman No. 9 of 2009 on Local Organizational Apparatus. This regulation controls the local organizational apparatus; one of which is Regional Land Controlling Board (BPPD) . Regional Regulation No. 9 of 2009 stipulates that the institution was called Regional Land Controlling Board Regional Regulation No. 8 of 2014 was followed up by the stipulation of Regency Regulation of Sleman No. 24.1 of 2014 on Description of Duties, Functions, and Work Procedures of the Public Works and Housing Agency.

BPPD, according to Regional Regulation No. 9 of 2009, has the following functions:

1. Formulation of technical policies on land sector;

2. Implementation of duties on land sector;

3. Implementation of public services on land sector;

4. Guidance and development on land sector; and

5. Implementation of other duties mandated by the Regent according with its duties and functions.

According to Regional Regulation No. 8 of 2014, on the other hand, BPPD has functions as follows:

1. Formulation of technical policies on land use control;

2. Implementation of duties on land use control;

3. Guidance and coordination on land use control; and

4. Implementation of other duties mandated by the Regent according to its duties and functions.

Spatial planning, based on both Article 17 of Regional Regulation No. 9 of 2009 and Article 18 Paragraph 1 Letter e of Regional Regulation No. 8 of 2014, is still the responsibility of Public Works and Housing Agency. However, based on Regional Regulation No. 9 of 2009 , no division of the agency is assigned to take charge in spatial planning. In other words, it is not clear who is responsible for spatial planning. Meanwhile, Regional Regulation No. 8 of 2014 stipulates that spatial planning is specifically assigned for Spatial Planning and Building Division of Detailed Spatial Planning Section at the Public Works and Housing Agency. Pursuant to Regional Regulation No. 11 of 2016 in lieu of Regional Regulation No. 8 of 2014, Land and Spatial Planning Agency Type B was formed to replace Regional Land Controlling Board in order to manage government affairs in land and spatial planning. Through Regional Regulation No. 11 of 2016, spatial planning, which was previously handled 
by Public Works and Housing Agency, is now one of the duties and functions of Land and Spatial Planning Agency.

According to Article 3 of Regional Regulation No. 11 of 2016, further provisions regarding the position, organizational structure, duties, and functions of regional apparatus are regulated by Regent Regulation. Hence, in order to implement government affairs in land and spatial planning, Regent Regulation of Sleman No. 66 of 2016 on Position, Organizational Structure, Duties and Functions, as well as Administration on Land and Spatial Planning was issued.

As stipulated in Regent Regulation No. 66 of 2016, Land and Spatial Planning Agency has the following duties and functions:

1. formulation of work plan of Land and Spatial Planning Agency;

2. formulation of technical policies on land and spatial planning;

3. implementation, service, guidance, and control of government affairs in land and spatial planning sectors;

4. evaluation and report on the implementation of government affairs in land and spatial planning sectors;

5. implementation of secretariat services; and

6. implementation of other duties mandated by the Regent according to its duties and functions and/or according to rules and regulations.

Spatial Planning Division, however, has the following duties and functions according to Article 19 of Regent Regulation No. 66 of 2016:

1. formulation of work plan of Spatial Planning Division;

2. formulation of technical policies on guidance on regency spatial planning;

3. guidance on regional spatial planning and detailed spatial planning;

4. guidance on building planning and environmental planning; and

5. evaluation and preparation of work implementation reports on Spatial Planning.

As specified in Article 30 of Regent Regulation of Sleman No. 24 of 2014 on Description of Duties, Functions, and Work Procedures of Public Works and Housing Agency, Spatial Planning Division works under the Public Works and Housing Agency and is part of Detailed Spatial Planning Section. Detailed Spatial Planning Section is responsible for preparing materials for implementation, guidance, and control of detailed spatial, building, and environmental planning. As mentioned above, Regent Regulation of Sleman No. 24.1 of 2014 is the implementing regulation of Regional Regulation No. 8 of 2014.

As stipulated in Article 31 of Regent Regulation No. 24.1 of 2014, Detailed Spatial Planning Section, in performing its duties, is responsible for preparing materials for:

1. work plan of Detailed Spatial Planning Section;

2. formulation of technical policies on detailed spatial, building, and environmental planning;

3. implementation, guidance, and control of detailed spatial, building, and environmental planning; and

4. evaluation and work implementation reports of the Detailed Spatial Planning Section.

Institutional dynamics of spatial planning are very interesting to observe. It should be remembered that spatial planning at the level of central government rests with the Ministry of Agrarian Affairs and Spatial Planning/National Land Agency. To this day, however, spatial planning in regions remains the responsibility of Public Works and Housing Agency (except in Yogyakarta). In Yogyakarta, spatial planning is no longer the duty of Public Works and Housing Agency, but now the responsibility of Land and Spatial Planning Agency. It should be noted, however, that Land Agency is different from Land Office. Land and Spatial 
Planning Agency of Sleman Regency is a regional agency, while Land Office of Sleman Regency is a vertical agency.

Organizational restructuring of spatial planning agency affects not only the authority over spatial planning, but also human resources. This means that Land and Spatial Planning Agency is given additional authority over spatial planning from Public Works and Housing Agency. This is in line with the national policy that spatial planning, which was originally handled by the Ministry of Public Works and Housing, is now managed by the Ministry of Agrarian Affairs and Spatial Planning/National Land Agency. The establishment of Land and Spatial Planning Agency is the manifestation of Article 97 Paragraph 1 of Regional Regulation No. 3 of 2015 on Local Government Institutions of Yogyakarta Special Region, which states that the Regency government should manage and strengthen institutions, especially in terms of special affairs of Yogyakarta Special Region which include institutions, culture, land issues, and spatial planning.

According to Regional Regulations No. 2 of 2017 on Spatial Planning of Sultanate Land and Regency Land, Regional Regulation No. 12 of 2012 on Spatial Planning of Sleman Regency in 2011 and 2031, and Regent Regulation of Sleman No. 66 of 2016 on Position, Organizational Structure, Duties and Functions, as well as Administration of Land and Spatial Planning Agency, the authority of Land and Spatial Planning Agency over spatial planning is presented in Table 1.

Table 1. Authority of Land and Spatial Planning Agency over Spatial Planning in Sleman

\begin{tabular}{|c|c|c|}
\hline $\begin{array}{c}\text { Article } 44 \text { of Special } \\
\text { Regional Regulation DIY } \\
\text { No. } 2 \text { of } 2017\end{array}$ & $\begin{array}{c}\text { Article } 3 \text { of Regional } \\
\text { Regulation of Sleman No. } \\
12 \text { of } 2012\end{array}$ & $\begin{array}{l}\text { Article } 19 \text { of Regent Regulation of Sleman } \\
\text { No. } 66 \text { of } 2016\end{array}$ \\
\hline $\begin{array}{l}\text { Implement authority to } \\
\text { facilitate the manifestation } \\
\text { of spatial planning of } \\
\text { Sultanate Land and Regency } \\
\text { Land, if requested by } \\
\text { Provincial Government in } \\
\text { terms of: } \\
\text { a. preparation of Detailed } \\
\text { Spatial Planning in the } \\
\text { Sultanate Land and the } \\
\text { Regency Land strategic } \\
\text { spatial units; } \\
\text { b. preparation of Detailed } \\
\text { Building and } \\
\text { Environmental Planning } \\
\text { in the Sultanate Land } \\
\text { and the Regency Land } \\
\text { strategic spatial units; } \\
\text { c. preparation of the } \\
\text { master plan in the } \\
\text { Sultanate Land and the } \\
\text { Regency Land strategic } \\
\text { spatial units; } \\
\text { d. implementation of } \\
\text { spatial planning; } \\
\text { e. monitoring and control } \\
\text { of the utilization of the } \\
\text { Sultanate Land and the }\end{array}$ & $\begin{array}{l}\text { Stipulation of policies on } \\
\text { regional spatial planning } \\
\text { covers: } \\
\text { a. integration and } \\
\text { development of activity } \\
\text { centers outside disaster } \\
\text { areas; } \\
\text { b. management of natural } \\
\text { disaster prone areas and } \\
\text { geological protected } \\
\text { areas; } \\
\text { c. preservation of } \\
\text { environmental functions; } \\
\text { development of } \\
\text { agricultural areas to } \\
\text { achieve food security; } \\
\text { development of } \\
\text { integrated tourism } \\
\text { destinations; } \\
\text { development of } \\
\text { education areas; } \\
\text { g. development of } \\
\text { environmentally-friendly } \\
\text { medium, small, and micro } \\
\text { industries; } \\
\text { h. development of safe, } \\
\text { comfortable, and } \\
\text { environmentally friendly }\end{array}$ & $\begin{array}{l}\text { Duties and functions for: } \\
\text { a. preparation of work plan of Land and } \\
\text { Spatial Planning Agency; } \\
\text { b. formulation of technical policies on } \\
\text { governmental affairs on land sector and } \\
\text { spatial planning sector; } \\
\text { c. implementation, service, guidance, and } \\
\text { control on governmental affairs in land } \\
\text { sector and spatial planning sector; } \\
\text { d. evaluation and implementation reports of } \\
\text { governmental affairs in land sector and } \\
\text { spatial planning sector; } \\
\text { e. implementation of secretariat services; and } \\
\text { f. implementation of other duties mandated } \\
\text { by the Regent according to its duties and } \\
\text { functions and/or rules and regulations. }\end{array}$ \\
\hline
\end{tabular}




\begin{tabular}{|l|l|l|}
\hline $\begin{array}{l}\text { Regency Land that } \\
\text { violate Spatial }\end{array}$ & $\begin{array}{l}\text { residential areas; } \\
\text { Planning; }\end{array}$ & i. $\begin{array}{l}\text { stabilization of } \\
\text { infrastructure; and } \\
\text { f. } \begin{array}{l}\text { handling of disputes } \\
\text { over the utilization of } \\
\text { the Sultanate Land or } \\
\text { the Regency Land; } \\
\text { defensens for national } \\
\text { preparation of } \\
\text { technical } \\
\text { considerations for the } \\
\text { spatial utilization } \\
\text { permit; } \\
\text { control over the spatial } \\
\text { utilization; and } \\
\text { supervision of the } \\
\text { spatial planning } \\
\text { implementation. }\end{array}\end{array}$
\end{tabular}

Based on the table above, the authority of Land and Spatial Planning Agency covers the spatial planning of the Sultanate Land and the Regency Land and the spatial planning of other areas. Meanwhile, the spatial planning of other areas besides Yogyakarta rests with the Public Works and Housing Agency.

\section{Conclusion}

1. Organizational restructuring of regional apparatus in Sleman Regency Yogyakarta regarding spatial planning should comply with policies imposed by the government, Regional Regulations, and the organizational structure of regional apparatus. The urgency of organizational restructuring of regional apparatus aims to achieve the effectiveness of the exercise of authority over spatial planning.

2. The authority of Land and Spatial Planning Agency of Sleman Regency over spatial planning is not limited to the spatial planning of the Sultanate Land and the Regency Land.

\section{References}

[1] Deliana VitaSari Djakaria and Rahmawati Husein, 2017, "Effectiveness of Regional Land Control Agency (KPPD) in Controlling the Utilization of Land through Allotment Permit Land Use (IPPT) (A Study in Gamping Sub-District, Sleman Regency)", Journal of Governance and Public Policy UMY, Vol. 4 No. 2, 253-293, http://doi.org/10.18196/jgpp.4278

[2] Nadia Astriani, 2014, "Implications of Green Space Policies in Spatial Planning in West Java", Journal of Legal ScienceUnila, Fiat Justisia, Vol. 8 No 2. 242-254. https://doi.org/10.25041/fiatjustisia.v8no2

[3] Ni'matul Huda, 2009.Hukum Pemerintahan Daerah.Bandung: Nusa Media

[4] Rizky Aulia, 2017, Authority of National Land Agency (BPN) under the Ministry of Agrarian Affairs and Spatial Planning/BPN, Undergraduate Thesis, Faculty of Law, Universitas Lampung.

[5] Robbins Stephen, 2006, Perilaku Organisasi, Edisi kesepuluh. Jakarta: PT Indeks Kelompok Gramedia. 